\title{
KULTURA LITERACKA ROSYJSKOJĘZYCZNEGO IZRAELA. SPORY WOKÓL „NARODOWOŚCI” LITERATURY
}

\author{
Agnieszka LENART (Katolicki Uniwersytet Lubelski Jana Pawła II)
}

Do 1989 roku władza sowiecka, mimo że jej przedstawiciele podpisali wiele międzynarodowych dokumentów ugodowych w tej sprawie, nie zezwalała Żydom na wyjazd do Izraela. Oczywiście zdarzały się indywidualne przypadki, jednak do czasu oficjalnego uznania przez Moskwę Izraela za historyczną ojczyznę swoich obywateli żydowskiego pochodzenia pod koniec lat 80., repatriacja była praktycznie niemożliwa ${ }^{1}$. Świadczą o tym liczby. Największa fala repatriacji rosyjskich Żydów nastąpiła w latach 1990-2003 i przywiodła do Izraela około miliona osób (wcześniej w latach 70. XX w., po wojnie sześciodniowej, nastąpiła krótkotrwała odwilż w stosunkach rosyjsko-izraelskich i wówczas napłynęło do Izraela ok. 200 tysięcy rosyjskich Żydów) ${ }^{2}$.

Nie ma wątpliwości, że znaczną cześć tych dwóch fal repatriacji żydowskiej z ZSRR stanowili przedstawiciele elit intelektualnych, reprezentanci świata kultury i literatury. Choć kultura literacka w Izraelu stopniowo słabnie, ma po dziś dzień ogromne znaczenie w życiu rosyjskojęzycznych Żydów i wymaga gruntownych badań.

Tezę tę potwierdza chociażby fakt, iż Państwo Izrael zamieszkuje obecnie ponad milion rosyjskich Żydów, z czego ponad 200 nazwisk figuruje w wykazie członków tamtejszego Związku Pisarzy Rosyjskojęzycznych. Na początku lat dwutysięcznych każdego roku drukiem ukazywało się w Izraelu 300-500 tytułów rosyjskich ${ }^{3}$. Oczywi-

1 Я. Рои, Еврейская эмиграчия из Советского Союза, 1948-1967, [w:] Еврейская эмиграция из России 1881-2005, ред. О. Будницкий, Москва 2008, s. 187.

${ }^{2}$ Zob.: M. Tolts, The Post-Soviet Jewish Population in Russia and in the World, Jews in Russia and Eastern Europe, 2004 nr 1 (52), Справочник Союза русскоязычных писателей Израиля 1990 год, 1999 год, Издание Союза русскоязычных писателей Израиля и Федерации Союзов писателей Израиля, Слово писателя, Осень 2002, Зима 2002, Зима 2004.

${ }^{3} \mathrm{Z}$ mojej korespondencji z sekretarzem Związku Pisarzy Rosyjskojęzycznych w Izraelu, Leonidem Finkelem (czerwiec 2015). 
ście rozmaita jest jakość tej literatury, jednak z pewnością możliwość obcowania z twórczością literacką pozwoliła rosyjskim Żydom podjąć dialog z przeszłością, a następnie stworzyć w Izraelu swoją małą ojczyznę, co w przyszłości doprowadzi zapewne do zupełnej asymilacji.

Niełatwa sytuacja twórców w sowieckiej Rosji, będąca dla wielu z nich główną przyczyną opuszczenia rosyjskiej ojczyzny, nadała procesowi historycznoliterackiemu w Rosji szczególny charakter. Badaczy literatury, ale również samych autorów, nierzadko zajmowała refleksja nad klasyfikacją literatury, tworzonej poza ojczyzną. O złożoności problemu „narodowości” literatury, tworzonej w warunkach ojczyźnianej bifurkacji, świadczy mnogość sformułowań, używanych dla nazwania tego zjawiska. Twórczość, o której mowa, określana była jako „literatura emigracyjna”, „emigracyjny rękaw literatury rosyjskiej”, ,zagraniczna gałąź literatury rosyjskiej”, „literatura na wygnaniu”, „literatura rosyjskiej zagranicy”, „literatura diaspory”, wreszcie „Rosja poza Rosją,", a także „Zagraniczna Rosja”, „Inna Rosja”, „Wolna literatura”4.

W kwietniu 1978 r. w Genewie odbyło się międzynarodowe sympozjum slawistyczne, poświęcone literaturze rosyjskiej, tworzonej poza granicami kraju. Zastanawiano się wówczas nad klasyfikacją pisarstwa metropolii i zagranicy, literatury tworzonej „tu” i „tam”. Georges Nivat, francuski historyk i slawista, rozpoczynając konferencję, zadał pytanie, które wyznaczało poniekąd porządek obrad. Brzmiało ono: „Jedna czy dwie literatury rosyjskie?"5. Uczestnicy sympozjum podejmowali próby rozwikłania problemu przynależności literatury rosyjskiej zagranicy, jej stosunku do literatury krajowej ${ }^{6}$. Podtrzymywali raczej tezę, że literatura jest jedna, a jeśli dochodzi do podziału literatury na dwie, o czym mówił Jefim Etkind, zwykle jest to proces długotrwały, uwzględniający specyficzne uwarunkowania.

$\mathrm{Na}$ początek naszych rozważań przytoczę stanowiska jednoznacznie definiujące literaturę rosyjskojęzyczną w Izraelu jako część literatury rosyjskiej. Odwołam się do relacji z wyprawy literatów rosyjskich do Izraela, która miała miejsce w 2003 roku. Pisarz Walerij Popow, przewodniczący Związku Pisarzy w Petersburgu, odbył wówczas wraz z innymi twórcami podróż do Izraela, by sprawdzić, jak się tam miewa literatura rosyjska ${ }^{7}$ (w wyjeździe wzięli udział: Michaił Ajzenberg, Wasilij Aksionow, Anatolij Najman, Andriej Bitow, Ludmiła Ulickaja). Popow, podkreślając ogromne, wręcz życiodajne znaczenie tej literatury, pisze:

Кончается, что ли, русская литература, а вместе с нею — и наша жизнь? Вот, думаю, главная тревога, главный вопрос, ради которого мы поехали. Ведь жизнь каждого из нас, из нашей литературной группы, несмотря на разницу талантов, судеб, возрастов, национальностей, питается только русской литературой, больше ничем ${ }^{8}$.

Troska o losy literatury, co wynika z przywołanego cytatu, dotyczy nie tylko badaczy literatury, ale także samych literatów. Z obserwacji Popowa, zawartych w antologii

${ }^{4}$ Zob.: L. Suchanek, Literatura rosyjska jest tam, gdzie znajduja się pisarze rosyjscy, [w:] Emigracja i tamizdat. Szkice o wspótczesnej prozie rosyjskiej, red. L. Suchanek, Kraków 1993, s. 54.

${ }^{5}$ Ж. Нива, Одна или две русских литературы? Симпозиум в Женеве (1978), Женева 1981, s. 3.

${ }^{6}$ Zob.: L. Suchanek, Literatura rosyjska, s. 54-55.

${ }^{7}$ В. Попов, Жизнь чужая и моя, Нева $2005 \mathrm{nr} 4$, s. 137-149.

${ }^{8}$ Tamże, s. 140. „Czy umiera literatura rosyjska, a razem z nią również nasze życie? Myślę, że te obawy były główną przyczyną naszego wyjazdu. Przecież życie każdego z nas, z naszej grupy literackiej, nie patrząc na różnicę talentów, losów, wieku, narodowości, żywi się tylko literaturą rosyjską, niczym więcej” [wszystkie tłum. — A.L.]. 
Marka Zajczika В Израиль и обратно. Путешествие во времени и пространстве (Do Izraela i z powrotem. Podróż w czasie i przestrzeni), wynika, że kultura literacka rosyjskiej alii utrzymywała się wówczas na wysokim poziomie. Popow z satysfakcją stwierdził, że rosyjskojęzyczne życie literackie w Izraelu funkcjonuje bardzo dobrze, sale spotkań z czytelnikami wypełnione były po brzegi, co nie świadczy o szybkim schyłku literatury, pisanej tam przez rosyjskich Żydów (niektórzy badacze twierdzą, że taka sytuacja potrwa dwa pokolenia, następnie w sposób naturalny wygaśnie). ${ }^{9}$. Pogląd, że literatura pisana w Izraelu stanowi część kultury rosyjskiej, wyrażał przedstawiciel rosyjskich Żydów, mieszkających w Izraelu, Dmitrij Segal, uczestnik wspominanej wcześniej konferencji w Genewie. Badacz ten, teoretyk literatury, zwraca jednak uwagę na fakt, że literatura tworzona za granicą stale wymaga dokładnej analizy i traktowania na równi $\mathrm{z}$ literaturą metropolii. Pisarze mający możliwość tworzenia $\mathrm{w}$ innych warunkach niż rzeczywistość ojczyźniana, zdaniem Segala, z powodzeniem wzbogacają literaturę krajową o nowe literackie trendy. Literatura metropolii z kolei stopniowo „oswaja” doświadczenia prozy emigracyjnej, czerpie z niej „nową krew”. Jeśli zaś chodzi o niejednorodność literatury, jest to zjawisko naturalne, charakterystyczne dla wielu literatur narodowych. Segal utrzymuje, że cała twórczość „rosyjskojęzycznego Izraela" stanowi część kultury rosyjskiej ${ }^{10}$. Powołując się na wypowiedzi Tomasza Manna i Wiktora Niekrasowa, możemy pokusić się o stwierdzenie, że „literatura rosyjska jest tam, gdzie znajdują się pisarze rosyjscy"11.

Zastanówmy się, jak w takim razie wygląda kwestia samoidentyfikacji literatury rosyjskojęzycznej, pisanej w Izraelu. Nie ulega wątpliwości, że twórczość przedstawicieli rosyjskiej alii komplikuje i tak złożoną już sytuację samoidentyfikacji literatury rosyjskiej pisanej za granicą, dotyczy przecież literatów, którzy wracali do ojczyzny swoich przodków. Proces masowego wyjazdu Żydów ze Związku Radzieckiego, szczególnie w latach 70. i 90. XX wieku, wpisuje się w badaniach literaturoznawczych w zjawisko nazywane „trzecią falą” emigracji rosyjskiej ${ }^{12}$. Również autorzy rosyjskich antologii, mam tutaj na myśli Władimira Agienosowa czy Sergieja Czuprynina, umieszczają nazwiska twórców rosyjskojęzycznej literatury żydowskiej w rozdziałach poświęconych literaturze rosyjskiej zagranicy ${ }^{13}$. Argumenty Jacka Leociaka przemawiałyby raczej za tym, by nazywać rosyjskich Żydów, żyjących w Izraelu, Izraelczykami, obywatelami Izraela, co poddaje w wątpliwość trafność określenia tej twórczości mianem „literatury emigracyjnej”, ${ }^{4}$. Mnogość interpretacji fenomenu, nad którym pochylali się, m.in. Benedykt Sarnow, Władimir Kunin, Władimir Lazaris, Leonid Kogan, Lazar Berenson, po raz kolejny wskazuje na jego wieloaspektowość. W krytyce literackiej o literaturze, powstającej po rosyjsku w Izraelu, pisze się: literatura rosyjska, izraelska, żydowska, ale także literatura będąca prowincją literatury rosyjskiej czy „wymuszona anomalia”, „obce ciało” (takich określeń użył Abraam Czerniak) ${ }^{15}$.

Stanowisk jest wiele i z pewnością nie znajdziemy terminu, który zadowoliłby wszystkich. Nie o to zresztą tutaj chodzi, naszym celem jest raczej nakreślenie złożo-

\footnotetext{
${ }^{9}$ Zob.: Л. Черкасский, Судить обо всем предвзято, Слово писателя, Осень 2002, s. 92.

${ }^{10}$ Zob.: Ж. Нива, Одна или две русских литературыз?, s. 43, 86.

${ }^{11}$ Cyt. za: L. Suchanek, Literatura rosyjska, s. 55.

${ }^{12}$ Zob.: A. Wołodźko, Wstęp, [w:] tejże, Pasierbowie Rosji, Warszawa 1995, s. 28.

${ }^{13}$ Zob.: В. В. Агеносов, Племя младое, незнакомое..., [w:] tegoż, Литература Russkogo зарубежья, Москва 1998, s. 509-510.

${ }^{14}$ Zob.: J. Leociak, Na obu brzegach, Nowe Książki 1994 nr 3, s. 70.

${ }^{15}$ Zob.: С. Бломберг, Путеводитель по объединениям русскоязычных литераторов Израиля, http://www.jerusalem-korczak-home.com/np/np58.html (dostęp: czerwiec 2015).
} 
ności problemu, która wynika z bogactwa skomplikowanej tożsamości rosyjskojęzycznych twórców żydowskiego pochodzenia. Karolina Famulska-Ciesielska we Wstępie do leksykonu Literatura polska w Izraelu pisze o „podwójnej przynależności” literatury pisanej w Izraelu po polsku. Według autorki owa twórczość „obok krajowej i emigracyjnej - stanowi trzeci stan skupienia" ${ }^{\text {"I }}$. Idąc tropem badaczki, twórczość rosyjskich Żydów-Izraelczyków, należałoby więc zaliczyć do literatury rosyjskiej, czerpie ona bowiem z bogactwa języka, tradycji i kultury rosyjskiej. W dodatku literatura ta nosi wyraźne ślady sowieckiej mentalności ${ }^{17}$. Jednak bez wątpienia przecież rosyjscy Żydzi w Izraelu są Izraelczykami. A więc, powołując się na sądy Leociaka, trzeba stwierdzić, że reprezentują również literaturę izraelską ${ }^{18}$.

Wątpliwości budzi również określenie „literatura rosyjska w Izraelu”. Decyzja rosyjskich Żydów o wyjeździe do Izraela, często traktowana jako „powrót do ojczyzny”, dla wielu wiązała się przecież ze świadomością bycia „nie-Rosjanami”, „pasierbami”, „z poczuciem półsieroctwa, krzywdy, samotności”" "Znaczna część rosyjskich Żydów - także prozaików i poetów - nie tyle wyjeżdżała do Izraela, ile uciekała ze Związku Radzieckiego, od ojczyzny-macochy, pełnej prześladowań i aktów antysemityzmu, tej również, która pozbawiła ich wolności, nie pozwalała być homo humanus, istnieć dla siebie i dla społeczeństwa, wreszcie skazała na tułaczkę, nierzadko odbierając dorobek ich dotychczasowego życia. Nie bez powodu więc Efraim Bauch, przewodniczący Związku Pisarzy Rosyjskojęzycznych w Izraelu, prezes Izraelskiego Oddziału PEN Clubu, w artykule jubileuszowym z okazji trzydziestolecia istnienia związku, mówiąc o sytuacji twórcy w państwie sowieckim, nazywa literaturę „częścią władzy, tylnym ogrodem nomenklatury" 20 .

Wielu wybór Izraela na nową ojczyznę dawał poczucie względnej niezależności, często również był deklaracją bezpowrotną, wiązał się $\mathrm{z}$ utratą paszportu i obywatelstwa. Dla wielu również wyjazd ten miał charakter twórczy, misyjny ${ }^{21}$. Pisze o tym Alicja Wołodźko w monografii Pasierbowie Rosji, powołując się na słowa Jefima Etkinda: „Pisarze rosyjscy nie uciekali z kraju — pragnęli tylko jednego: być pisarzami, zajmować się literaturą, jednak w ZSRR droga ta była dla nich zamknięta bądź się przed nimi zamykała"22. Opuszczenie ZSRR, a później również Rosji, dla wielu rosyjskojęzycznych twórców było niewątpliwie ucieczką od cenzury. Wyjazd dawał nadzieję na możliwość nieskrępowanego wyrażania swoich myśli, pisania prawdziwej literatury, swobodnego głoszenia niezaprzeczalnych wartości. Ważną przyczyną opuszczenia Rosji był brak nadziei na zmiany w funkcjonowaniu państwa. Mówią o tym słowa Piotra Czaadajewa, cytowane przez rosyjskojęzyczną pisarkę, od 1991 r. mieszkającą w Izraelu, Dinę Rubinę: „Nie nauczyłem się kochać ojczyzny na kolanach, z za-

${ }^{16}$ K. Famulska-Ciesielska, Wstęp, [w:] Literatura polska w Izraelu, red. K. Famulska-Ciesielska, S. Żurek, Kraków-Budapeszt 2012, s. 5.

${ }^{17}$ Por. także: Литературная эмиграция 1960-1990-х годов (третья волна), [w:] Литература русского зарубежья, под общ. ред. А. И. Смирновой, Москва 2006, s. 444-445.

${ }^{18}$ Zob. tamże.

${ }^{19}$ Por. A. Wołodźko, Wstęp, s. 32-33.

20 Э. Баух, Скромная дань апологии. К 30-летию Союза русскоязычных писателей Израиля, Слово писателя, Осень (1) 2002, s. 3.

${ }^{21}$ Zob.: Г. Костырченко, Политика советского руководства в отнотении еврейской эмиграчии после ХХ съезда КПСС (1956-1991), [w:] Еврейская эмиграчия из России 18812005, Материаль международной научной конференции (Москва, 10-12 декабря 2006), отв. ред. О. В. Будницкий. Москва 2008, s. 205.

${ }^{22}$ Cyt. za: tamże, s. 41. 
mkniętymi oczami i zatkanymi ustami" ${ }^{23}$. Decyzja pisarki i jej rodziny o wyjeździe z Rosji była reakcją na uciążliwą sowiecką rzeczywistość i narastającą falę nacjonalistycznych i antysemickich zachowań. Rubina miała wrażenie, że w podobnych okolicznościach nic więcej napisać nie zdoła, wyjeżdżała, jak sama mówi, z kraju ubezwłasnowolnienia, nacisku, braku szacunku i poniżenia. „Wyjeżdżając w roku dziewięćdziesiątym, zupełnie dobrowolnie, złożyłam u stóp władzy sowieckiej i obywatelstwo, i mieszkanie. To był mój własny wybór". ${ }^{24}$ - mówi pisarka.

Sytuacja twórców rosyjskich była bardzo skomplikowana, zawód literata wiązał się z dużym ryzykiem. Dowodem jest chociażby wypowiedź Grigorija Kanowicza, Żyda, który młodość spędził na Litwie, obecnie zaś mieszka w Bat-Jamie. Kanowicz wspomina, że rodziców bardzo niepokoił jego talent pisarski, od dziecka wpajali mu, że pióro jest narzędziem zdradliwym, często bywa przyczyną aresztowań i prześladowań $^{25}$. Literatura niezależna mogła w Rosji sowieckiej istnieć dzięki ruchom dysydenckim, publikacjom podziemnym i ogromnemu zaangażowaniu samych twórców. Wydanie we Włoszech powieści Doktor Żywago Borysa Pasternaka zapoczątkowało powstanie tzw. tamizdatu, czyli publikowanie za granicą dzieł zakazanych w ZSRR. Możliwość wydawania na Zachodzie, będąca uzupełnieniem samizdatu - wydawnictw drugiego obiegu - pozwoliła na omijanie surowych zasad publikacji w Gosizdacie (wydawnictwach państwowych) i na przełamanie monopolu cenzury, dzięki czemu wiele rosyjskojęzycznych dzieł literackich i publicystycznych mogło w końcu ujrzeć światło dzienne ${ }^{26}$. Pisarze, także ci o korzeniach żydowskich, z poświęceniem walczyli o swobodę twórczą i o jakość literatury. Należy jednak wspomnieć, że pojawiają się również krytyczne wypowiedzi pod adresem rosyjskich Żydów, którzy zdecydowali się wyjechać z kraju. Alicja Wołodźko nazywa je stanowiskiem „tendencyjnym" ${ }^{27}$. Michaił Nazarow jako główny powód masowych wyjazdów Żydów pod koniec XX wieku wymienia chęć „lepszego życia”, zarzuca twórcom żydowskim kosmopolityzm i brak patriotyzmu ${ }^{28}$.

O fenomenie rosyjskojęzycznego Izraela pisze Leonid Czerkasskij w artykule zamieszczonym na łamach czasopisma „Słowo pisatelia” z okazji trzydziestolecia Związku Pisarzy Rosyjskojęzycznych w Izraelu. Artykuł obszernie traktuje kwestie narodowej przynależności twórcy i literatury rosyjskojęzycznej, powstającej w Izraelu, bardziej jednak wskazuje na złożoność problemu niż jednoznacznie odpowiada na nurtujące pytania. Czerkasskij w części zatytułowanej Великий и могучий... (Wielki i potężny...) pisze o sile języka jako niezaprzeczalnym elemencie samoidentyfikacji człowieka, ale także, odwołując się do skomplikowanej sytuacji rosyjskojęzycznych Żydów w Izraelu, jako o czymś, co jest również piętnem, które naznacza człowieka

${ }^{23} \mathrm{Z}$ mojej korespondencji z pisarką, maj 2010.

24 „Уезжая в 90-м, я, само собой, сложила к ногам Советской власти и гражданство, и квартиру... Это был мой собственный выбор". Tak o przyczynach opuszczenia ZSRR mówiła Rubina podczas spotkania z czytelnikami w Centrum Kultury Żydowskiej w Krakowie 24.10.2008 (nagranie z prywatnego archiwum). Jako główny powód wyjazdu z Rosji pisarka wymieniła wówczas widoczne na ulicach Moskwy przejawy antysemityzmu w postaci napisów antyżydowskich.

25 Г. Канович, Штрихи к автопортрету, Иерусалимский журнал $2008 \mathrm{nr} 27$, http://magazines.russ.ru/ier/2008/27/ka11.html (dostęp: czerwiec 2015).

${ }^{26}$ Zob.: L. Suchanek, Literatura rosyjska, s. 53-54.

${ }^{27}$ Zob.: A. Wołodźko, Wstęp, s. 29.

${ }^{28}$ Zob.: М. Назаров, Миссия русской эмиграции, т. 1, Ставрополь 1992, s. 11. Zob. także: A. Wołodźko, Wstęp, s. 29. 
przez całe życie. Czerkasskij nie podważa konieczności przyswojenia języka kraju zamieszkiwania, szczególnie jeśli chodzi o kraj przodków. Historyczne uwarunkowania, dodaje autor, sprawiły jednak, że język rosyjski dla sporej grupy Żydów rosyjskich, zamieszkujących kraj „powrotu”, przez jakiś czas jeszcze pozostanie językiem komunikacji. W sposób naturalny również jest on językiem tworzonej przez nich literatury $^{29}$ :

Я всегда был убежден в необходимости изучения языка страны проживания, тем более - „страны возвращения”. Тут нет предмета для дисскуссий. Речь идет об исторически сложившейся ситуации, приведшей к тому, что русский язык еще долгое время останется языком общения и культуры для значительных групп граждан, а тоже языком русскоязычной литературы. Явление естественное и закономерное ${ }^{30}$.

W kolejnej części artykułu, zatytułowanej Как нас теперь называть? (Jak nas teraz nazywać?), autor pisze o wielu próbach określenia społecznego i twórczego statusu literatów piszących po rosyjsku. Spory wokół samoidentyfikacji rosyjskich Żydów pisarzy lub rosyjskich pisarzy-Żydów, jak twierdzi, są uzasadnione, ale też wpisują się w proces tworzenia się narodu izraelskiego i jego kultury. Czerkasskij powołuje się na wypowiedź klasyka literatury hebrajskiej Chaima Bialika z 1916 roku na temat „,narodowości" utworu literackiego. Zdaniem Bialika nie język dzieła literackiego jest najważniejszy, lecz klimat, duch, w jakim jest ono napisane. Według wieszcza literatury żydowskiej o przynależności literatury decydują bardziej subiektywne czynniki: przywiązanie autora do danego narodu, jedność duszy twórcy z duszą narodu, z jego kulturą, wreszcie dbałość o jego historię — przeszłość, teraźniejszość i przyszłośćc ${ }^{31}$ :

Национальность литературного произведения определяется не языком, на котором оно появилось, а господствующим настроением автора, его тягой к определенному народу, сродством души автора с душой родного народа, с его культурой, устремлением к прошлому, настоящему и будущему этого народа; определяется ответом на вопрос, для кого он работает и чьи национальные интересы защищает ${ }^{32}$.

Podobną koncepcję popularyzował także historyk Szymon Dubnow, żydowski historyk i pisarz przełomu XIX i XX wieku, który — powołując się na twórczość Szymona Fruga, urodzonego na Krymie poety żydowskiego, piszącego początkowo tylko w języku rosyjskim, potem w jidysz, następnie zaś po hebrajsku — przekonywał, że Żydzi na przestrzeni wieków posługiwali się wszystkimi językami świata, co wpłynęło

29 Л. Черкасский, Судить обо всем предвзято, s. 92.

${ }^{30}$ Tamże. „Zawsze byłem przekonany o konieczności opanowania języka kraju zamieszkania, szczególnie «kraju powrotu». To nie podlega dyskusji. Sprawa dotyczy sytuacji uwarunkowanej historycznie, która sprawiła, że język rosyjski jeszcze przez długi czas będzie językiem komunikacji i kultury znacznej części obywateli, a także językiem literatury rosyjskojęzycznej. Jest to zjawisko naturalne".

31 Tamże. Por. także: В. Львов-Рогачевский, Русско-еврейская литература, Moskwa 1922, s. 44-46, В. Жаботинский, Еврейский легион, Москва 2013, s. 15-18. В. Чернин, Многого реб Хаим-Шулим и не разобрал... Идиш как субстрат русского языка Осипа Рабиновича, Лехаим, декабрь 2006 Кислев 5767-12 (176).

32 В. Львов-Рогачевский, Русско-еврейская литература, s. 49. „Narodowość dzieła literackiego określana jest nie poprzez język, w którym to dzieło się pojawiło, ale przez pryzmat dominującego nastroju autora, jego bliskości z określoną społecznością, powinowactwem duszy autora $\mathrm{z}$ duszą rdzennych mieszkańców, ich kultury, tęsknotą za przeszłością, spojrzeniem na teraźniejszość i przyszłość tego narodu; zawiera odpowiedź na pytanie dla kogo on pracuje i czyje narodowe interesy chroni”. 
na utworzenie wielu warstw językowych ich literatury. Fakt ten na szczęście, stwierdza Dubnow, nie pozbawił literatury żydowskiej wewnętrznej jedności i narodowej tożsamości:

Еврейство, на своем долгом историческом пути пользовалось всеми языками культурного мира от древне-греческого до нынешнего русского, только, как орудиями своего духовного творчества, - вследствие чего образовались большие иноязычные пласты нашей литературы, но от этого последняя не утратила своей внутренней цельности и национальной самобытности ${ }^{33}$.

Literatura rosyjsko-żydowska, według historyka, również cierpiąca za naród żydowski, pokazuje duszę narodu wędrującego, odzwierciedla postawy żydowskie, żydowskie rozumienie świata, mentalność żydowską. A wszystko to odbywa się także za pośrednictwem literatury rosyjskiej:

В русско-еврейской литературе, также страдавшей за еврейский народ, отразилась душа народа - странника, [...] еврейское мироощущение, мирочувствование и миропонимание, определенный душевный ритм, еврейский образ мыслей, еврейская культура, еврейский быт... Все это прошло сквозь призму русской литературы ${ }^{34}$.

Pisarze rosyjscy w Izraelu, mimo wszelkich trudności imigracyjnych i aklimatyzacyjnych, są więc w dosyć komfortowej sytuacji. Po pierwsze, co stale podkreśla Efraim Bauch, powrócili do korzeni, po drugie mogą posługiwać się powszechnie używanym językiem rosyjskim, którym rozbrzmiewają ulice izraelskich miast i miasteczek, co pozwala literatom uczestniczyć w życiu codziennym nowej ojczyzny i inspiruje do pracy ${ }^{35}$. Język, nazywany przez Dinę Rubinę piętnem, które prześladuje człowieka przez całe życie, dla Grigorija Kanowicza stanowi „ojczyznę — na szczęście taką, którą wszędzie można zabrać ze sobą"36.

Pisarz Jakow Szechtior, przewodniczący Klubu Literatów w Tel-Awiwie, w wywiadzie dla gazety „Wiesti” potwierdza skomplikowaną sytuację tożsamościową rosyjskich twórców w Izraelu. Jego zdaniem pisarze żydowscy w Izraelu znajdują się w ustawicznym konflikcie między kulturą języka a językiem kultury. Alicja Wołodźko w monografii Pasierbowie Rosji uczula na problemy, z którymi borykają się rosyjscy Żydzi literaci, piszący na styku kultur. Piętno narodowościowe było, według Wołodźko, przyczyną wielu konfliktów, znajdujących odzwierciedlenie w pisarstwie autorów pochodzenia żydowskiego i w życiu samych twórców, „Żydów z pochodzenia, Rosjan z wychowania, wykształcenia, języka i kultury"37. Taka sytuacja jednak, zdaniem Szechtiora, ma także pozytywne strony, wpływa bowiem na szczególny koloryt tworzonej w Izraelu literatury:

${ }^{33}$ Tamże, s. 44-50. „Żydzi, na swojej długiej historycznej drodze, wykorzystywali wszystkie języki cywilizowanego świata, od starogreckiego do współcześnie używanego rosyjskiego, wyłącznie jako narzędzia swojej duchowej twórczości - w wyniku czego wykształciły się rozległe obcojęzyczne warstwy naszej literatury, mimo to nie utraciła ona swojej wewnętrznej ciągłości i narodowej oryginalności”.

${ }^{34}$ Tamże. „W literaturze rosyjsko-żydowskiej, również cierpiącej za naród żydowski, znalazła odzwierciedlenie dusza narodu-tułacza [...], żydowska wrażliwość, postrzeganie świata, światopogląd, charakterystyczny duchowy rytm, żydowski sposób myślenia, kultura żydowska, życie Żydów... Wszystko to odbywało się przez pryzmat literatury rosyjskiej”.

35 Э. Баух, Скромная дань апологии, s. 3.

${ }^{36} \mathrm{Z}$ mojej korespondencji z pisarzami.

${ }^{37}$ Zob.: A. Wołodźko, Wstęp, s. 29. 
Пишущий по-русски еврейский писатель пребывает в перманентном конфликте между культурой языка и языком культуры. Возможно именно поэтому [...] эта литература особенно интересна. Искусство ради искусства в масштабе целой страны $^{38}$.

Szechtior, podobnie zresztą jak wielu innych pisarzy rosyjskojęzycznych w Izraelu (mam tu na myśli Dinę Rubinę, Grigorija Kanowicza czy Igora Gubermana), podkreśla, że nieprzerwanie istnieć będzie jego ścisła więź z Rosją, że zawsze odczuwać będzie ciężar dziedzictwa kulturowego i przywiązanie do języka rosyjskiego, jedynego, w którym może tworzyć. „C Россией меня связывает груз культурного наследия и язык, единственный, на котором я могу писать"з9, przyznaje w wywiadzie dla „Wiesti” Jakow Szechtior.

Również Anatolij Mucznik, rozpatrując istotę literatury tworzonej w Izraelu, zwraca uwagę na ogromne znaczenie języka rosyjskiego w budowaniu i utrwalaniu narodowej świadomości — bardzo złożonej, ale z pewnością wyjątkowej:

Современные теоретики, придают огромное значение роли языка как основного инструмента национального сознания. Они ссылаются на то, что многие европейцы видят в родном языке и литературе залог своей национальной целостности, даже создают академии по защите языка и порой ведут настоящую войну за сохранность языковых границ ${ }^{40}$.

Niektórzy krytycy podkreślają uniwersalizm literatury żydowskiej. Wielość języków, jakimi posługują się twórcy żydowscy, tworzy przecież jej właściwy charakter. Pisarz izraelski, o czym mówi między innymi Leonid Kogan, jeśli nie jest po prostu rosyjskim pisarzem, który wybrał Izrael na swoją ojczyznę, jest przecież pisarzem żydowskim ${ }^{41}$. A twórcy żydowscy piszą nie tylko w języku jidysz czy po hebrajsku, ale także po rosyjsku, rumuńsku, niemiecku czy po bułgarsku. Twórczość pisarza żydowskiego przepełniona jest ,żydowskością”, kontynuuje Kogan. Kultura żydowska stanowi jego przeszłość i przyszłość, wypełnia jego historię, życie, wyznacza dążenia i priorytety. Najważniejszym wyznacznikiem, określającym „narodowość” literatury, jest, według twórcy, sposób postrzegania przez literata świata i ludzi, a także motywy, które dominują w jego twórczości. Miejsce pobytu autora nie ma jego zdaniem Kogana znaczenia. Przytaczając poglądy Kogana, Leonid Czerkasskij przywołuje również stanowisko profesora Aarona Czerniaka, aktywnego działacza zajmującego się spra-

${ }^{38}$ Д. Клугер, Искусство ради искусства в масштабе иелой страны, Вавилонская библиотека, Вести 26.11.2008, http://sunround.com/club/pressa/kluger_shehter.htm (dostęp: kwiecień 2011). „Pisarz żydowski piszący po rosyjsku przebywa w permanentnym konflikcie między kulturą języka i językiem kultury. Możliwe, że właśnie dlatego [...] ta literatura jest szczególnie interesująca. Sztuka dla sztuki w skali całego kraju”.

${ }^{39}$ Tamże. „Z Rosją wiąże mnie ciężar dziedzictwa kulturowego i język, jedyny, w którym mogę pisać".

А. Мучник, Проблемы языка в еврейской литературе и русско-еврейская литература. Еврейская литература или литература евреев?, http://samlib.ru/m/muchnik_a_m/01lit.shtml (dostęp: czerwiec 2015). „Współcześni teoretycy podkreślają dużą rolę języka jako podstawowego narzędzia świadomości narodowej. Powołują się na to, że wielu Europejczyków dostrzega w rodzimym języku i literaturze gwarancję swojej tożsamości narodowej, a nawet tworzą akademie ochrony języka, a czasem prowadzą prawdziwą wojnę o zachowanie granic językowych".

${ }^{41}$ Суt. za: Л. Черкасский, Судить обо всем предвзято, s. 93. 
wami rosyjskich Żydów i zagranicy ${ }^{42}$. Uczony podkreślał często wagę języka jako jednego z najbardziej wiarygodnych kryteriów dla określenia pojęć „żydowska literatura” i „żydowski pisarz”. Mimo że Czerniak akcentował również rangę literatury żydowskiej, pisanej w językach nieżydowskich, w tym także w języku rosyjskim, znawcy jego teorii przytaczają jego przeciwstawne poglądy, na przykład używane przez Czerniaka, a wspomniane już wcześniej, określenia „ciało obce”, „wymuszona anomalia”, świadczące o złożoności analizowanego problemu, literatury „swojej”, jeśli chodzi o treść, jednak „obcej” w ujęciu językowym ${ }^{43}$.

Fenomen rosyjskojęzycznej literatury w Izraelu, co podkreśla Leonid Czerkasskij, jest niewątpliwie częścią historii literatury izraelskiej, mimo mocnego zakorzenienia w kulturze rosyjskiej stopniowo staje się wypadkową recepcji międzykulturowej, nabierając również izraelskiego kolorytu.

Za wyrwanie ze swojej kultury — pisze Ryszard Kapuściński — płaci się wysoką cenę.

Dlatego tak ważne jest posiadanie własnej, wyraźnej tożsamości, poczucie jej siły, wartości i dojrzałości. Tylko wówczas człowiek może śmiało konfrontować się z inną kulturą. W przeciwnym wypadku będzie chować się w swojej kryjówce, bojaźliwie odgradzać się od innych. Tym bardziej, że Inny to zwierciadło, w którym się przeglądam czy — w którym jestem oglądany, to lustro, które mnie demaskuje i obnaża, czego wolelibyśmy jednak uniknąc $c^{44}$.

Nie ma wątpliwości, że - zgodnie ze słowami Dawida Markisza - twórczość rosyjskojęzycznych literatów w Izraelu jest takim właśnie lustrem, zwierciadłem, które weryfikuje, obnaża, demaskuje ich tożsamość, ale również pozwala im żyć w niełatwej emigracyjnej rzeczywistości, chroniąc jednocześnie przed zdziczeniem. Literatura rosyjska w Izraelu, podkreśla Leonid Finkel, jest pamiętnikiem przeszłości, przewodnikiem, który staje się inspiracją do głębszych poszukiwań wiedzy na temat ludzkości $^{45}$. Nie dziwi więc fakt, że próby określenia statusu literatury rosyjskojęzycznej pisanej przez Żydów w Izraelu, podejmowane przez badaczy literatury i przez samych twórców, są często odrzucane, krytykowane, uznane za niepotrzebne. W obronie kultury tworzonej na pograniczu kultur i za odrzuceniem wszelkich podziałów na gruncie literatury kategorycznie wypowiada się Dina Rubina. Powołując się na teorie Bachtina, stwierdzić można, że pisarka tworzy prozę, która zespala różnorodne tradycje, jednak, według niej, literatura jest jedna ${ }^{46}$. Próby usystematyzowania badanej literatury być może potęgują u samych twórców poczucie półsieroctwa, samotności. Mówił o tym Grigorij Kanowicz w jednym z wywiadów:

Jestem pisarzem samotnym. Całkiem samotnym - i w ludzkim, i w literackim sensie. Wielokrotnie mówiłem, że nie jestem pisarzem żydowskim, bo piszę po rosyjsku. Nie jestem pisarzem rosyjskim, bo piszę o Żydach. Nie jestem litewskim pisarzem, bo piszę o Żydach i po rosyjsku, a teraz język rosyjski traktowany jest na Litwie jak inne obce

${ }^{42}$ Zob.: Ю. Систер, М. Пархомовский, Памяти Арона Яковлевича Черняка, Мы здесь. Публикации http://www.newswe.com/index.php?go=Pages\&in=print\&id=8179 (dostęp: październik 2015).

${ }^{43}$ Por.: Л. Черкасский, Судить обо всем предвзято, s. 93.

${ }^{44}$ R. Kapuściński, Spotkanie z Innym jako wyzwanie XXI wieku, Kraków 2004, s. 12.

${ }^{45} \mathrm{Z}$ mojej korespondencji z Leonidem Finkelem, sierpień 2010.

46 Э. Ф. Шафранская, Мифопоэтика „иноэтнокультурного текста” в русской прозе Дины Рубиной, Москва 2007, s. 230. Zob.: L. Liburska, Emigracja, [w:] tejże, Kultura i inteligencja rosyjska. O pisarstwie Lidii Czukowskiej, Kraków 2003, s. 329. 
języki, na równi ze szwedzkim, angielskim czy suahili. Jestem więc obcym pisarzem we własnej ojczyźnie ${ }^{47}$.

Kanowicz czuł się obco w swojej ojczyźnie - na Litwie. Obco czuł się również w Izraelu, dokąd wyjechał w roku 1993. Język rosyjski nazywa Kanowicz, jak pamiętamy, rodzajem piętna. Piętnem nazywa pisarz również swoją nieokreśloną przynależność literacką, co jednak ma jego zdaniem również dobre strony — powoduje pewną niezależność, rozumianą w tym wypadku jako swoboda twórcza. Z drugiej jednak strony obciąża wiecznym poczuciem obcości.

Pozostawiając spory o klasyfikację literatury, pisanej przez rosyjskich twórców w Izraelu, bez jednoznacznej odpowiedzi, zakończę swoje rozważania, przywołując słowa Dmitrija Kanowicza. Syn Grigorija Kanowicza w jednej z wypowiedzi prasowych podkreśla uniwersalizm prozy ojca. Mówi o głoszonych przez niego wartościach, które przecież nie mają narodowości ${ }^{48}$. Być może podobnie wygląda kwestia przynależności literatury rosyjskojęzycznej, tworzonej w Izraelu. Według Leonida Czerkasskiego jest ona zjawiskiem czasowym, „krótkim przystankiem” na drodze długiego procesu historycznoliterackiego ${ }^{49}$. Efraim Bauch mówi, że literatura ta odzwierciedla ogromny proces „koczowania”, ale także w niektórych przypadkach pozyskania ojczyzny odkrywa magię i zarazem tragedię tego zjawiska, co wpływa na jej niewątpliwie wyjątkowy charakter ${ }^{50}$.

\section{LITERATURA:}

В. В. Агеносов, Литература Russkogo зарубежья, Москва 1998;

Э. Баух, Скромная дань апологии. К 30-летию Союза русскоязычных писателей Израиля, Слово писателя, Осень (1) 2002, s. 2-3;

С. Бломберг, Путеводитель по объединениям русскоязычных литераторов Израиля,

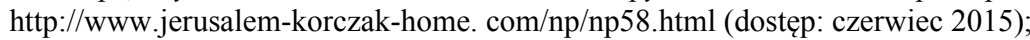

Л. Черкасский, Судить обо всем предвзято, Слово писателя, Осень 2002, s. 92- 94;

В. Чернин, Многого реб Хаим-Шулим и не разобрал... Идиш как субстрат русского языка Осипа Рабиновича, Лехаим, декабрь 2006, Кислев 5767-12 (176), http://www.lechaim. ru/ARHIV/176/chernin.htm (dostęp: grudzień 2015);

Emigracja i tamizdat. Szkice o wspótczesnej prozie rosyjskiej, red. L. Suchanek, Kraków 1993;

Г. Канович, Штрихи к автопортрету, „Иерусалимский журнал” $2008 \mathrm{nr}$ 27, $\mathrm{http} / / /$ magazines.russ.ru/ier/2008/27/ka11.html (dostęp: czerwiec 2015);

R. Kapuściński, Spotkanie z Innym jako wyzwanie XXI wieku, Kraków 2004;

Д. Клугер, Искусство ради искусства в масштабе иелой страны, „Вавилонская библиотека”, Вести 26.11.2008, http://sunround.com/club/pressa/kluger_shehter.htm (dostęp: kwiecień 2011);

Г. Костырченко, Политика советского руководства в отношении еврейской эмиграции после ХХ съезда КПСС (1956-1991), [w:] Еврейская эмиграция из России 1881-2005, Материалы международной научной конференции (Москва, 10-12 декабря 2006), отв. ред. О. В. Будницкий. Москва 2008, s. 202-219;

J. Leociak, Na obu brzegach, Nowe Książki 1994, nr 3, s. 70-71;

L. Liburska, O pisarstwie Lidii Czukowskiej, Kraków 2003;

${ }^{47}$ Zob.: Pisarz samotny. Z G. Kanowiczem rozmawiat A. Kozioł, Dekada Literacka 1993 nr $12 / 13(72 / 73)$

${ }^{48}$ В Вахтанговском театре пройдет премьера спектакля Улыбнись нам, Господи, 7 маpта 2014, http://tass.ru/kultura/1027609 (dostep: marzec 2014).

${ }^{49}$ Por.: Л. Черкасский, Судить обо всем предвзято, s. 93.

${ }^{50}$ Zob.: Э. Баух, Скромная дань апологии, s. 3. 
Literatura polska w Izraelu, red. K. Famulska-Ciesielska, S. Żurek, Kraków-Budapeszt 2012; Литература русского зарубежья, под общ. ред. А. И. Смирновой, Москва 2006;

В. Львов-Рогачевский, Русско-еврейская литература, Москва 1922;

А. Мучник, Проблемы языка в еврейской литературе и русско-еврейская литература. Еврейская литература или литература евреев?, http://samlib.ru/m/muchnik_a_m /01lit.shtml (dostęp: czerwiec 2015);

М. Назаров, Миссия русской эмиграции, т. 1, Ставрополь 1992;

Ж. Нива, Одна или две русских литературы? Симпозиум в Женеве (1978), Женева 1981;

Pisarz samotny. Z G. Kanowiczem rozmawiał A. Kozioł, Dekada Literacka 1993 nr 12/13 (72/73), s. 7-10;

В. Попов, Жизнь чужая и моя, Нева 2005, nr 4, s. 137-149;

Я. Рои, Еврейская эмиграция из Советского Союза, 1948-1967, [w:] Еврейская эмиграция из России 1881-2005, ред. О. Будницкий, Москва 2008, s. 187-201;

Д. Рубина, Наш человек в Израиле, Вокруг Света, $2008 \mathrm{nr} 5$ (2812);

Ю. Систер, М. Пархомовский, Памяти Арона Яковлевича Черняка, Мы здесь. Публикаиии $\mathrm{http}: / /$ www.newswe.com/index.php?go=Pages\&in=print\&id=8179 (dostęp: październik 2015];

Э. Ф. Шафранская, Мифопоэтика „иноэтнокультурного текста” в русской прозе Дины Рубиной, Москва 2007;

M. Tolts, The Post-Soviet Jewish Population in Russia and in the World, [w:] Jews in Russia and Eastern Europe, 2004, nr 1 (52), s. 37-63;

A. Wołodźko, Wstęp [w:] tejże, Pasierbowie Rosji, Warszawa 1995;

В. Жаботинский, Еврейский легион, Москва 2013.

\section{LITERARY CULTURE OF RUSSIAN-SPEAKING ISRAEL. DISPUTES OVER THE "NATIONALITY" OF LITERATURE}

This article focuses on the issues of the literary culture of Russian-speaking Israel as well as on the categorization of belonging of Russian-Jewish literature written in Israel. It is impossible to unequivocally define the creative status of Russian-speaking authors in Israel, or to clearly delimit the "nationality" of the literature written by them, as indicated by literary critics, literary scholars and writers themselves. The analysis of the question of the Russian Jews' departure from Russia is complemented by research on the functioning of the Russian Alijah in Israel, as well as with comments of the causes of Russian Jews' emigration from Russia, while also discussing the situation of the authors in Soviet Russia and their position in the new homeland.

KEYWORDS: Russian-language Israeli literature; Russian-Jewish literature; belonging; nationality.

\section{ЛИТЕРАТУРНАЯ КУЛЬТУРА РУССКОЯЗЫЧНОГО ИЗРАИЛЯ. СПОРЫ ВОКРУГ „НАЦИОНАЛЬНОСТИ” ЛИТЕРАТУРЫ}

В статье рассматривается тема литературной культуры русскоязычного Израиля, приводятся размышления на тему принадлежности русско-еврейской литературы в Израиле. Нельзя однозначно ответить на вопрос о творческом статусе русскоязычных писателей в Израиле, определить „национальность” этой литературы. Приведенные в тексте взгляды литературных критиков, литературоведов и самих писателей подтверждают эти выводы. Анализ пополняют исследования о функционировании русской алии в Израиле, называющие причины выезда русских евреев из России, указывающие на сложную ситуацию литератов в советской России и их положение на новой родине.

КЛЮЧЕВЫЕ СЛОВА: русскоязычный Израиль; русско-еврейская литература; принадлежность; национальность. 